УДК: 811.16:929 Куљбакин С. DOI: https://doi.org/10.18485/belic_slv.2017.2.ch2

Радојица Јовићевић

\title{
ДОПРИНОС СТЈЕПАНА КУљБАКИНА СРПСКОЈ ПАЛЕОСЛАВИСТИЦИ
}

Стјепан Михаилович Куљбакин родио се 28. јула 1873. године у Тифлису (данашњи Тбилиси), где је завршио гимназију. На Новоросијском универзитету у Одеси дипломирао је 1896. године. Био је један од најзапаженијих ученика познатих професора - слависте Александра Александровича Кочубинског и класичара Штерна и Никитског. Као студент одликован је златном медаљом за научни рад „Питање о глагољици и ћирилици". Припремајући се за катедру словенске филологије на Универзитету у Одеси, Куљбакин је од 1896. до 1900. године радио у библиотекама Петрограда и Москве. У Москви је слушао предавања Филипа Фјодоровича Фортунатова, а учествовао је и на скуповима који су се одржавали у Фортунатовљеву дому. То је време када се у Русији окупљало око Фортунатова и Шахматова све што се бавило филологијом и лингвистиком. О том времену писао је касније и Александар Белић, који је био прешао на Московски универзитет после четири семестра проведена у Одеси, где је с Куљбакином започео друговање, пријатељство и научну сарадњу за сав живот. Говорећи о руској лингвистичкој школи и сећајући се скупова четвртком увече у кући једног од својих најуваженијих учитеља, Филипа Фјодоровича Фортунатова, после две деценије Белић дочарава ту атмосферу:

„... дубоко у ноћ, говорило се о научним питањима свих врста, и млађи су имали прилике да виде сву способност, широко знање и оштроумност својих учитеља који су у разговору, у шали, само са неколико речи умели мајсторски да оцртају какав језички појам, језички покрет у земљи или изван ње, или какву научну индивидуалност. Сви научници почетници и старији, руски и инострани, образовали су у тој кући једну духовну породицу. Колико се пута потписаноме - наставља Белић - тада студенту Московског универзитета, десило да види кога од прослављених научника Русије и Европе у кући Фортунатовљевој и (да) осети сву интимност која је међу присутнима владала! Проф(есори) Корш, Шахматов, Покровски, Поржезински, Грушка, Соколов, Брант, Всев. Миљер, 
Шчепкин (В. Н.) и толики други били су обични гости Фортунатова; од странаца Бернекер, О. Брок, Т. Торбјернсон, П. Боаје, Ф. Солмсен и др(уги) пробавили су по који семестар у Москви као слушаоци Фортунатовљеви и били су примани као и његови најближи ученици. Иначе сви остали, ближи и даљи ученици и поштоваоци Фортунатова, као Уљанов, Томсон, Љапунов, Куљбакин, Ендзелин, Карски, Собољевски и многи други, који су били у другим университетима, долазили су у Москву да поздраве патријарха лингвистике, који је имао (и) подједнаке љубави и поштовања за све и необичне природности у опхођењу са свима. Ти састанци, то стално општење са свима, разговори о свим питањима науке и подстицаји за нове радове били су много значајнији него многи институти и семинари. На њима је научни интерес био уздигнут до једних од сталних и свакидашњих потреба живота човечијег и једног од његових првих занимања. Њему се све остало потчињавало." (А. Белић, Руска лингвистичка школа, Јужнословенски филолог II, Београд 1921, 169-179).

Из Москве се Стјепан Куљбакин вратио у Одесу, где је септембра 1900. постављен за доцента словенске филологије, а већ у априлу 1901. године, одлуком Министарства просвете, кренуо је на двоипогодишње научно путовање по европским славистичким центрима и по словенским земљама. Радио је у библиотекама Берлина, Лајпцига, Беча, Прага, Београда, Софије, Кракова, Лавова. У околини Познања проучавао је пољске дијалекте, у околини Будишина лужички језик, а у северној Чешкој чешке дијалекте. У Београду је боравио у децембру 1902. и у јануару и фебруару 1903. године. Септембра 1904. изабран је за ванредног професора словенске филологије на Харковском универзитету. Докторску дисертацију „Охридская рукопись апостола конца XII века” одбранио је у Петрограду маја 1908. и истог месеца изабран је за редовног професора Харковског универзитета. На тој дужности остао је до децембра 1919. Тада је дошао у Србију и одмах, 1920. постављен је за професора старословенскога језика у Скопљу. Исте године изабран је за дописног, а за редовног члана Српске академије наука 1925. Годину дана раније прешао је на Београдски универзитет. Умро је 22. децембра 1941. и сахрањен је у руској парцели на београдском Новом гробљу.

У некрологу, објављеном готово после десет година у првом послератном броју Јужнословенског филолога (1950), Александар Белић жали за искреним другом и пријатељем, „с којим га је везивало право пријатељство од студентске клупе до старости”, што му је „значило и у научном правцу врло много”. „Наш универзитет и наша наука - каже Белић - много дугују Куљбакину. Никада обрада старословенског језика, његових најстаријих и познијих споменика, није вршена са толико 
познавања предмета као у Куљбакиновим радовима (исп. његову засебну расправу о старословенском језику у „Мирослављеву јеванђељу”). У малој групи наших стручњака окупљених око Лингвистичког друштва „Јужнословенског филолога” и „Нашег језика” он је био један од најистакнутијих и највреднијих чланова" (Јужнословенски филолог XIII, Београд 1949-1950, 504-506).

Угледом слависте-компаративисте, који је већ имао у научноме свету, професору Стјепану Куљбакину су била отворена врата сваког универзитета на којем се проучавао макар један словенски језик. Уз чињеницу да се Стјепан Куљбакин, још у својим првим научним радовима, као старословениста и компаративиста бавио и најстаријим српским споменицима и историјом српскога језика, уз чињеницу да је већ имао два издања своје књиге „Сербский язык” (1915. и 1917) и „Хрестоматию по сербскому языку" (1915), нема сумње да је на његово опредељење за Србију имало утицаја и давнашње пријатељство и научна сарадња с Александром Белићем.

На Београдском универзитету Стјепан Куљбакин је предавао у првом реду старословенски језик, а затим словенску и јужнословенску палеографију. Држао је и специјални курс о Ћирилу и Методију, а једног семестра предавао је и увод у лингвистику. Предавања проф. Куљбакина су била изванредно систематична и методична - сећа се његов некадашњи ученик, а наш професор Ђорђе Живановић. Студенти су с интересовањем пратили Куљбакинова предавања и били су оспособљени да активно учествују у вежбањима из старословенског језика. А мимо часова, често су узајамне поруке писали - глагољицом.

Меша Селимовић - који је марта 1934. дипломирао на групи за Српски језик и југословенску књижевност пред комисијом у саставу Александар Белић, Стјепан Куљбакин и Бранко Милетић - у својим „Сјећањима” пише да је имао срећу и да је стигао да слуша предавања Богдана Поповића, Павла Поповића, Владимира Ћоровића, Веселина Чајкановића, Стјепана Куљбакина, Александра Белића... „Заиста, велика имена!” узвикује Меша Селимовић и наставља: „Са задовољством исписујем имена својих универзитетских професора. Они спадају међу највеће свјетске слависте и међу највеће научнике у својим струкама и жао ми је што од њих нисам више научио." Сећајући се појединачно свакога од њих, Меша Селимовић почиње именом: „Д-р Стјепан Куљбакин, аутор најбоље свјетске граматике старословенског језика, који је долазио на предавања готово потпуно паралисан, предавао је са зачуђујућом свјежином. Иако озбиљно оболио од Паркинсонове болести, никад није изостао са часова и вјежби, увијек спреман на стрпљив разговор са студентима о старо- 
словенском језику, који је феноменално знао. Али никада није хтио да се упушта у 'туђу' материју: једном сам га на вјежбама упитао за одређену појаву из историје језика (ангелос... анђео), а он ме замолио да упитам господина Белића, он се боји да није довољно стручан за ту област! А знао је исто колико Белић, али се строго држао своје научне сфере" (Меша Селимовић, Сјећаға - мемоарска проза, БИГЗ 1988, 90-92).

Куљбакинова граматика, коју спомиње Меша Селимовић, заиста спада у најбоље граматике старословенског језика. Као универзитетски уџбеник Куљбакинов „Древнецерковнословянский язык” имао је у Русији три издања (Харьков 1911, 1913. и 1917) и ушао је у састав „Энциклопедии славянской филологии". На чешком језику Куљбакинова граматика изишла је у Прагу 1928. и 1948, а на српском 1930. у Београду. Ипак, чешки и српски превод представљају знатно скраћено издање Куљбакинове граматике на француском језику, која је изишла у Паризу 1929. Није било неважно што у француском издању иза имена аутора пише: „професор Београдског универзитета”. Иако је Куљбакинова „Старословенска граматика” намењена као „уџбеник студентима који проучавају старословенски језик, давно је констатовано да је она знатно више него то: она представља збир најпродубљенијих знања о старословенском језику, изложених акрибично, систематично, методично и изнад свега - научно поуздано.

Из обимнога научног опуса Стјепана Куљбакина - за ову тематски и временски омеђену пригоду - осврнућу се у неколико речи само на неке његове радове, и то оне који се најнепосредније односе на наш језик.

У већ споменутој књизи „Сербский язык” Куљбакин у уводу наглашава да „в числе славянских языков сербский язык издавна пользуется особым вниманием как потому, что его данные очень ценны для сравнительной грамматики славянских языков, так и потому, что он является органом интересной литературы и богатейшей народной поэзии". Компаративно-историјским методом аутор даје кратак преглед развитка гласова, акцената, деклинације и конјугације српскога језика.

Одмах по доласку у Србију, године 1920, Куљбакин у издању Геце Кона објављује „Краткую сербскую грамматику для русских”, написану за руског емигранта, „волею судеб лишенного на время родины и живущего в Сербии". Ова практична граматика рађена је на научној основи, али сада не компаративно-историјским, него диференцијалним методом, пошто је код најважнијих одељака показана разлика између српскога и руског језика. Принципи састављања и методолошка упутства за учење граматике - о чему аутор говори у уводу - као и начин обраде језичке материје, ни данас - после више од седамдесет година - нису застарели. Та 
практична граматика нашега језика наишла је на велико интересовање, тако да је већ следеће (1921) године изишло ново издање.

У студији „Палеографска и језичка испитивања о Мирослављевом јеванђељу" (Сремски Карловци 1925) Куљбакин је дао детаљну ортографску, палеографску, језичку и текстолошку анализу најстаријег и најрепрезентативнијег споменика српске писмености. Куљбакинова студија спада међу најзначајније монографије о Мирослављеву јеванђељу.

Споменућу само још Куљбакинове „Лексичке студије” (Глас САН 1940), у којима аутор - на основу лексичких и морфолошких архаизама у најстаријим словенским преводима хомилија - утврђује везу језика Светога Саве и његових ученика с књижевним језиком Климента Охридског и Охридске школе.

Спомињања и издвајања су вредна два предлога што их је Стјепан Куљбакин поднео као члан Српске академије наука, а које је својим потписом подржао и Александар Белић. Оба та предлога наводим у целини (према Годишњаку СКА XXXIV, 249-250):

1. „Старословенски речник по споменицима који су нам познати из најстаријих епоха развитка старословенског језика. То је данашњи ріuт desiderium наше науке. Научник чешки Вацлав Вондрак радио је једно време на њему. Ако је тај посао проф. В. Вондрак - који је пре кратког времена умро и чија смрт представља осетни губитак за словенску науку - у знатној мери израдио, чешки би се научници свакако могли договорити да га, према карактеру који му је Вондрак дао, доврше, а све словенске академије, без разлике, морале би се постарати да он што пре угледа света. Јер много што-шта из најстаријих и најтамнијих времена развитка и словенских језика и словенских књижевности биће сасвим друкчије осветљено него данас што је, када будемо имали то дело.

У случају да је то довршавање Вондракова дела неизводљиво, требало би да тај посао предузму наше академије - Српска Краљевска и Југославенска споразумно. Ст. Куљбакин, А. Белић."

Напомена уз овај предлог: од 1958. године до сада су у Прагу објављене 44 свеске (последња одредница је ОУБЛАЖИТИ) и већ се назире скори завршетак овога капиталнога речника старословенског језика.

2. „Речник из књижевних старина српскохрватских. Даничићев речник из књижевних старина обухвата само један део наших споменика, и то само оних који су наштампани до 1863-4. год. После тога времена наштампан је много већи број таквих споменика него пре њега. Зато је потребно израдити нов речник те врсте.

Ми мислимо да у тај речник треба да уђе материјал из српскохрватских старина писаних црквеним језиком српскохрватским (и у ћирил- 
ским и глагољским и у штампаним и рукописним делима). То је управо старословенски језик, који је код Срба и Хрвата, а нарочито Срба, био једно време књижевним језиком, тако да се без доброг речника тих старина и саме те старине не могу разумети.

Обрада тога речника могла би се вршити у исто време у Београду и Загребу, за ћирилске споменике и глагољске, па би се завршна редакција могла дати једном лицу или већем броју лица. Ст. Куљбакин, А. Белић”...

Велики и изузетно значајан допринос нашој науци дао је Стјепан Куљбакин у „Јужнословенском филологу”, у којем је сарађивао од првога броја 1913. године (што је А. Белић у споменутоме некрологу превидео, наводећи да је Куљбакин био сарадник „Јужнословенског филолога” од другога броја, то јест, од године 1921). Куљбакин је у „Јужнословенском филологу" објавио велики број расправа, критичких приказа и оцена. Овде издвајам студију „Акценатска питања” (Јужнословенски филолог II и III), у којој Куљбакин расправља о словенском акценту, једном од најкомпликованијих и најзамршенијих питања упоредне граматике словенских језика. Посебну пажњу заслужују Куљбакинови критички прикази и оцене. Почев од првога броја „Јужнословенског филолога” - у којем је објавио критички приказ Јагићева рада „Глаголическое письмо”, Стјепан Куљбакин је редовно и мериторно обавештавао научну јавност о свим научним достигнућима у области компаративистике и палеославистике. Чак и у осамнаестоме броју „Јужнословенског филолога” - који је изишао девет година после Куљбакинове смрти - објављено је седам његових критичких прилога и оцена. Специфичност Куљбакинових критичких приказа је у томе што су готово сви прерасли у расправе о одређеним научним питањима.

Констатацију Александра Белића да „наш универзитет и наша наука много дугују Куљбакину” треба узети дословно, поготову што се зна да Белић није олако изрицао овакве судове. Кад је остао без отаџбине - а веровао је да је то само привремено - Стјепан Куљбакин је у Србији нашао домовину. Као и многи његови сународници од знања и умења - он је Србији узвратио оним што је имао, умео и знао. Тфмь сътворилъ кстъ

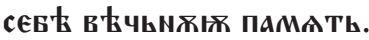


Радоица Йовичевич

\section{ВКЛАД СТЕПАНА КУЛЬБАКИНА В СЕРБСКУЮ ПАЛЕОСЛАВИСТИКУ}

Резюме

После краткой биографии Степана Михайловича Кульбакина, автор говорит о нем, как о преподавателе Белградского университета, в котором С. М. Кульбакин преподавал старославянский язык, славянскую и южнославянскую палеославистику и некоторое время введение в языкознание. Лекции Кульбакина отличались информативностью и методичностью. С целью подтверждения вышеупомянутого, автор приводит цитату из „Воспоминаний” Меши Селимовича.

Крупнейший вклад в сербскую палеославистику представляют собой ученые труды Кульбакина „Палеографические и языковедческие исследования Мирославова евангелия”, „Лексические исследования” и, в первую очередь, „Грамматика старославянского языка”. Выдающееся место занимают труды Кульбакина, опубликованные в журнале „Южнославянский филолог" с первого по восемнадцатый номера, в котором, посмертно, было опубликовано семь его работ.

В своем докладе автор, приводя данные, подтверждает давно высказанное мнение Александра Белича, что: „... наш Университет и наша наука многим обязаны Степану Михайловичу Кульбакину". 